\title{
Revitalisasi Identitas Diri Komunitas Masjid Saka Tunggal Banyumas, Masjid Raya Al Fatah Ambon, dan Masjid Agung Jami' Singaraja Bali dalam Perubahan Budaya Global
}

\author{
Ahmad Salehudin \\ Universitas Islam Negeri Sunan Kalijaga Yogyakarta, Indonesia \\ ahmad_salehudin@yahoo.co.id
}

\begin{abstract}
This study examines how three communal mosques: Masjid Saka Tunggal Cikakak Banyumas, Masjid Raya Al Fatah Ambon, and Masjid Agung Jami' Singaraja respond toward globalization. Globalization that is characterized with the territorial demarcations of states' administration jurisdiction, political currents, economic strata, and religions has shaped global villages with cultural homogeneity as its estuary. Strong cultures tend to crush the vulnerable cultures. These conditions tend to generate a dilemma for the existence of an identity, including the identity of communal mosques. However, communal mosques are not merely a set of inanimate objects which can only passively accept external influences. They are a collection of beings who "tactically" respond to the "strategy" of the global cultural cooptation. The result of this study reveals that communal mosques become a collective awareness of each its individual to respond to and live the life amidst the increasingly uncontrollable wave of global cultures. Global cultures, as long it benefits, are adapted and adopted to strengthen their communal identity and, otherwise, left when they bring disadvantages. In order to protect communal identities, the result of this study
\end{abstract}


offers three ways: habituation and institutionalization of the communal identity, reinforcing the ancestral authority, and affirming the institutional vision and mission.

Penelitian ini mengkaji respon tiga komunitas masjid, yaitu Masjid Saka Tunggal Cikakak Banyumas, Masjid Raya Al Fatah Ambon, dan Masjid Agung Jami’ Singaraja terhadap globalisasi. Globalisasi yang ditandai oleh menghilangnya batas-batas administrasi negara, aliraan politik, strata ekonomi, dan agama telah membentuk kampung global dengan homogenisasi budaya sebagai muaranya. Budaya yang kuat cenderung menggilas budaya yang lemah. Kondisi ini cenderung melahirkan dilema bagi eksistensi identitas, termasuk identitas komunitas masjid. Namun demikian, komunitas masjid bukanlah sekumpulan benda mati yang hanya bisa pasrah menerima pengaruh luar, tetapi sekumpulan mahluk hidup yang "taktik" untuk merespon "strategi" kooptasi budaya global. Hasil penelitian menunjukkan masjidmasjid komunitas menjadi collective awareness para individu untuk merespon dan menjalani kehidupan di tengah samudra budaya global yang semakin tak terkendali. Budaya global diadaptasi dan diadopsi selama bermanfaat untuk menguatkan identitas komunitasnya, dan bersikap acuh jika tidak sesuai atau membahayakan. Untuk melindungi identitas komunitasnya, ada tiga hal yang dilakukan, yaitu melalui pembiasaan dan pelembagaan identitas komunitas, meneguhkan otoritas leluhur, dan peneguhan visi misi lembaga.]

Keyword: globalization, identity, community, tactic, strategy. 


\section{Pendahuluan}

Masyarakat di seluruh dunia saat ini sedang ditransformasikan secara dramatis oleh globalisasi. ${ }^{1}$ Globalisasi telah menginteraksikan masyarakat yang bertebaran dengan segenap perbedaan ras, agama, dan geo-kultur yang dimilikinya berada dalam satu perkampungan besar yang disebut global village. ${ }^{2}$ Dengan jaringan teknologi informasi, masyarakat di suatu negara dengan di negara lain dapat berinteraksi tanpa hambatan waktu dan batas-batas kewilayahan. Kondisi ini kemudian disebut juga sebagai era globalisasi. ${ }^{3}$

Semua bidang kehidupan masyarakat saat ini telah dipengaruhi oleh globalisasi, ${ }^{4}$ termasuk pada komunitas keagamaan. ${ }^{5}$ Globalisasi tidak saja menjanjikan harapan-harapan yang indah bagi masyarakat, melainkan juga menimbulkan kegelisahan-kegelisahannya tersendiri. ${ }^{6}$ Misal, adanya

\footnotetext{
1 George Ritzer and Dougles J. Goodman, Teori Sosiologi Modern, terj. Alimandan (Jakarta: Prenada Media Group, 2004), 587.

2 M. Nurcholis Madjid, Islam Agama Kemanusiaan (Jakarta: Paramadina, 1995), 110.

3 A. Qodri Azizy, Melawan Globalisasi: Reinterpretasi Ajaran Islam (Yogyakarta: Pustaka Pelajar, 2004), 19-20; AsiaDHRRA Secretariat, The Impact Globalization on the SocialCultural Live of Grassroots People in Asia (Jakarta: Grasindo, 1998), 7.

4 Martin Wolf, Globalisasi Jalan Menuju Kesejabteraan, terj. Samsudin Berlian (Jakarta: Yayasan Obor Indonesia, 2007), xi; Firmanzah, Globalisasi: Sebuah Proses Dialektika Sistemik (Jakarta: The Ary Suta Center, 2007), 10.

${ }^{5}$ Menurut Down Browning seperti dikutip E. Gerrit Singgih, globalisasi memberikan arti sebagai: 1) misi universal dari gereja, 2) kerjasama ekumenis, 3) dialog diantara agama Kristen dengan agama-agama lain, dan 4) masalah ketidakadilan sosial. Lihat E. Gerrit Singgih, "Globalisasi dan Kontekstualisasi: Menuju Sebuah Kesadaran Baru Mengenai Realitas di Sekitar Kita," Renai: Jurnal Politik Lokal dan Sosial-Humaniora 2, no. 34, (2002): 44.

${ }^{6}$ Globalisasi dengan demikian menjadi paradok, di satu sisi ia membuat dunia menuju ke arah yang lebih demokratis; semakin banyak negara menghormati hak asasi manusia, kesetaraan, dan keterbukaan. Di sisi lain, ia juga menghasilkan penindasan dan dominasi baru yang membahayakan kemanusiaan, seperti maraknya perang, terorisme, dan kesenjangan distribusi kekayaan, baik di negara maju maupun negara berkembang. Lihat Firmanzah, Globalisasi: Sebuah Proses. 8-9.
} 
anggapan bahwa kebudayaan-kebudayaan di luar Barat harus menyesuaikan diri dengan gagasan-gagasan kultural Barat. ${ }^{7}$

Persoalan identitas masyarakat juga menduduki tempat yang unik di era globalisasi. ${ }^{8}$ Persoalan identitas ini menjadi semakin menguat dalam dinamika masyarakat Islam. Ada adagium dalam komunitas Muslim di Indonesia, bahwa globalisasi yang dianggap bias kebudayaan Barat merupakan aktor hegemonik yang telah mengakibatkan perubahan dalam sendi-sendi kehidupan sosial Islam, terutama timbulnya krisis identitas. Krisis identitas seperti pedang bermata dua, ke dalam dapat meneguhkan identitas sosialnya, namun keluar menjadi kontra produktif bagi eksistensi komunitas Islam itu sendiri, seperti munculnya stigmatisasi global atas Islam dengan aksi terorisme dan kekerasan yang dilakukan kelompok-kelompok radikal pada satu sisi, ${ }^{9}$ dan kegagalan Islam dalam memberikan kontribusi positif bagi globalisasi yang dipandang bias tersebut. ${ }^{10}$

Globalisasi juga menghasilkan persoalan atas diri identitas itu sendiri. ${ }^{11}$ Letak persoalannya ada ketika peneguhan identitas keagamaan, misalnya diekspresikan melalui gerakan resistensi yang menimbulkan

7 George Ritzer and Dougles J. Goodman, Teori Sosiologi Modern, 588; M. Nurcholis Madjid, Islam Agama Kemanusiaan, 110; Fredric Jameson and Masao Miyoshi eds., The Culture of Globalization (USA: Duke University Press, 2004), 32.

8 Martin Lukito Sinaga, Identitas Poskolonial Gereja Suku dalam Masyarakat Sipil (Yogyakarta: LKiS, 2004), 5.

${ }^{9}$ Muhammad Wildan, "Mapping Radical Islamism in Solo: A Study of the Proliferation of Radicalism in Central Java," al-Jamiab: Journal of Islamic Studies 46, no. 1 (2008): 61.

10 Perdebatan-perdebatan penting yang menggairahkan dalam mencari bentuk masyarakat ideal dan sistem kemasyarakatan yang sanggup mengangkat hajat hidup orang banyak terus berlangsung dalam era globalisasi ini. Demikian pula perdebatan mengenai gagasan-gagasan besar di bidang sosial, politik, agama, dan kebudayaan terus terjadi dalam berbagai bentuknya, terutama tema-tema besar di seputar hubungan Islam dan Barat di awal abad ke-21 ini. Lihat Martin Wolf, Globalisasi Jalan Menuju Kesejabteraan, xi.

${ }_{11}$ Globalisasi telah membuat banyak orang kehilangan orientasi dan definisi atas dirinya, sehingga mereka ingin kembali ke identitas dasarnya yang dibangun di atas dasar "materi tradisional bentukan dunia komunal." Identitas kemudian membantu mengatasi krisis individu maupun kelompok dengan membangun kembali makna yang hilang. Lihat Radjasa Mu'tasin (ed.), Model-Model Penelitian dalam Studi Keislaman (Yogyakarta: Lembaga Penelitian UIN Sunan Kalijaga, 2006), 83-84. 
stigmatisasi, sebagaimana yang dilakukan kelompok Laskar Jihad dalam konflik Muslim dan Kristen di Maluku sepanjang tahun 1999-2003. Kekristenan yang dianggap mewakili dunia Barat menimbulkan ancaman dan krisis identitas bagi sekelompok Muslim di Maluku, sehingga melahirkan konflik dan kekerasan berlarut-larut. ${ }^{12}$ Belum lagi munculnya gerakan terorisme dan aksi bom bunuh diri sebagai bentuk "perlawanan" atas globalisasi yang dianggap membahayakan identitas komunitas, seperti yang terjadi di Jimbaran dan Pantai Kuta Bali, Hotel Ritz Cartlon Jakarta, dan rangkaian aksi bom bunuh diri lainnya di Indonesia. ${ }^{13}$

Dalam konteks lokal, globalisasi juga melahirkan ruang-ruang responsi identitas kelompok dalam bentuk pengikatan diri pada kesadaran etnik dan budaya. Ketika kesadaran etnik dan budaya, bahkan agama bertemu, maka pembentukan identitas sosial kian menemukan vitalitasnya. ${ }^{14}$ Salah satunya adalah komunitas masjid. Masjid merupakan identitas bagi komunitasnya, sehingga menjadi bagian penting yang "terancam" oleh globalisasi. Namun demikian, hampir tidak ada peneliti yang mencoba melihat bagaimana upaya komunitas masjid dalam merespon globalisasi. Tulisan-tulisan tentang masjid lebih menitikberatkan pada aspek sejarahnya, ${ }^{15}$ dimensi fungsi masjid, ${ }^{16}$

12 Lihat Badrus Saleh, "Conflict, Jihad, and Religious Identity in Maluku, Eastern Indonesia," al-Jamiab: Journal of Islamic Studies 46, no. 1 (2008): 72, diakses 10 Desember 2016, https://doi.org/10.14421/ajis.2008.461.71-99.

13 Muhammad Harfin Zuhdi, "Radicalism and Effort De-Radicalization of Religious Understanding," dalam The Strategic Role of Religious Education in the Development of Culture of Peace (Jakarta: Center for Research and Development of Religious Education and Religion Ministry of Religious Affairs of the Republic of Indonesia, 2012), 252.

${ }^{14}$ Menurut Mead, identitas sosial yang dikaitkan dengan etnisitas bertolak dari konsep diri individu dalam berkelompok itu bersumber dari partisipasinya dalam budaya di mana ia dilahirkan dan diterima. Budaya diperoleh individu melalui simbol-simbol yang memberikan makna dengan cara eksprimentasi terus menerus sehingga membentuk ikatan kekeluargaan (familiarity). Deddy Mulyana, Metodologi Penelitian Kualitatif (Bandung: Remaja Rosdakarya, 2010), 231.

15 Lihat Supriyo Priyanto, Konservasi dan Pengembangan Masjid Agung Kauman Semarang untuk Identitas Budaya dan Pariwisata (Semarang: Departemen Pendidikan Nasional Universitas Diponegoro, 2000); Masmedia Pinem, "Masjid Pulo Kameng Akulturasi dan toleransi Masyarakat Aceh," Analisa 20, no. 1 (Januari-Juni 2013): 87-97.

${ }^{16}$ Lihat Sulkhan Chakim, "Estetika, Masjid, dan Dakwah," Ibda': Jurnal Studi Islam dan Budaya 3, no. 3 (Juli-Desember 2005): 1-9. 
arsitektur yang bersifat monumental, ${ }^{17}$ dan peran masjid dalam kehidupan masyarakat setempat. ${ }^{18}$

Tulisan Ahmad Salehudin dengan judul Satu Dusun Tiga Masjid: Anomali Ideologisasi Agama dalam Agama menyajikan fakta menarik bahwa masjid tidak hanya sebagai tempat ibadah, tetapi juga identitas kelompokkelompok keagamaan. Sebagai identitas, masjid menjadi ruang yang sangat terbatas, yaitu menjadi pemilah antara satu kelompok dengan kelompok yang lain. Namun demikian tulisan Salehudin tersebut belum membahas tentang bagaimana masjid sebagai identitas tetap eksis dalam budaya global. ${ }^{19}$

Pada kasus komunitas Masjid Saka Tunggal Banyumas, Masjid Al Fattah Ambon, dan Masjid Agung Singaraja Bali, identitas sosial tidak hanya mengalami revitalisasi melainkan juga dipakai untuk meresponsi perubahan budaya global. Namun, perubahan budaya global kekinian tentunya menimbulkan persoalan sendiri bagi identitas ketiga masjid tersebut. Ada tiga hal yang dibahas dalam artikel ini, yaitu mengapa hal itu dapat terjadi? bagaimana gambaran sosiologis-antropologisnya ketika identitas sosial terbentuk sekaligus menciptakan responsi atas perubahan budaya global? Dan adakah pengaruh perubahan budaya global tersebut terhadap eksistensi identitas komunitas ketiga masjid tersebut?

\section{Globalisasi dan Dinamika Identitas Komunitas}

Kata identitas berasal dari bahasa Inggris, identity, dan berakar dari bahasa Latin, idem yang berarti "sama" dan identidem yang berarti "berulang-ulang atau berkali-kali". Kedua istilah ini membentuk kata baru "identitas" yang berarti "sebelah menyebelah dengan mereka yang

\footnotetext{
${ }^{17}$ Lihat Yulia Eka Putrie, "Kontradiksi Simbol dan Substansi Nilai Islam dalam Arsitek Masjid," El-Qudwab 4 (2010).

18 Purwanto, "Peranan Keberadaan Masjid Agung Demak dalam Perkembangan Kehidupan Sosial Ekonomi dan Budaya Masyarakat Kelurahan Bintoro Kecamatan Demak Kabupaten Demak," Dimensi 2, no. 1 (November 2014).

19 Ahmad Salehudin, Satu Dusun Tiga Masjid: Anomali Ideologisasi Agama dalam Agama (Yogyakarta: Pilar Media, 2007).
} 
serupa (likeness) dan satu (oneness)." 20 Dengan demikian, secara harfiah kata identitas bermakna sama, baik sama dalam bentuk maupun isi. Identitas mencerminkan suatu kelompok yang mempunyai kesamaan dalam rupa yang diwujudkan ke dalam simbol dan atribut sosial di masyarakat. Simbol dan atribut kemudian mengikat isi, yakni karakteristik nilai dan cita-cita sosial yang sama yang menjadi identitas sosialnya.

Henri Tajfel adalah tokoh awal yang menggagas teori identitas sosial yang berkaitan dengan penjelasan mengenai prasangka, diskriminasi, konflik antarkelompok dan perubahan sosial. ${ }^{21}$ Tajfel membedakan antara proses kelompok dari proses yang di alami oleh individu. Jadi harus membedakan antara proses seseorang dari orang lain dan proses identitas sosial yang menentukan apakah seseorang dengan ciri-ciri tertentu termasuk atau tidak dalam kelompok sosial. ${ }^{22}$ Identitas merupakan proses dari keindviduan menuju pada proses berkelompok karena kesamaan ciri-ciri khusus dari masing-masing individu dalam berperilaku. Perilaku kelompok dapat berbeda dengan perilaku individu, sehingga setiap individu akan menciptakan identitas sosial di tengah identitas diri yang berproses, yang membantunya untuk mengonseptualisasi dan mengevaluasi diri sendiri. Identitas sosial juga mencakup banyak karakteristik unik, seperti nama seseorang, konsep diri, agama, gender, dan lain sebagainya.

Seorang komunitas Islam Aboge (alif rabo wage) yang hidup dan berkembang dengan berpusat di Masjid Saka Tunggal Cikakak Banyumas misalnya, dapat menjadi contoh baik bagaimana individu (penganut Islam Aboge) dan komunitasnya (kelompok Islam Aboge) berkembang dan berproses dengan cara yang berbeda. Identitas sebagai penganut Islam Aboge hanyalah satu dari sekian identitas yang melekat dirinya. Identitas sebagai penganut Islam Aboge melekat pada individu sebagaimana identitas-identitas lainnya melekat, misalnya sebagai ayah, menantu, petani, dan lain sebaginya. Identitas-identitas tersebut menjadi sumber

\footnotetext{
20 Markus Dominggus Lere Dawa, Teori-teori Sosial tentang Identitas (Makalah Program Doktor Sosiologi Agama UKSW Salatiga, 2011), 5.

${ }^{21}$ Idham Putra, "Teori Identitas Sosial," diposting 21 0ktober 2008, diakses 4 April 2015, https://coidhamputra.wordpress/2008/10/21/teori-identitas-sosial/ 22 Ibid.
} 
referensi bagaimana individu melakukan konseptualisasi dan sekaligus memaknai hidup dan kehidupannya. Dalam konteks ini, keberadaan komunitas Islam Aboge menjadi sangat penting bagi penganut Islam Aboge, yakni sebagai collective awareness untuk merespon dan menjalani kehidupannya.

Dalam kontek agama dan identitas, Hans Mol memberikan gambaran yang jelas tentang korelasi antara identitas dengan agama. Mol mengemukakan empat ciri peranan agama pada masyarakat atau juga disebut komunitas masjid yang menentukan pembentukan identitasnya. Pertama, agama berperan dalam dramatisasi dialektika dalam masyarakat, yang lazim disebut mitos dalam bentuk keyakinan primitif dan kebijaksanaan moral, teologi dalam agama-agama dunia, dan ideologi dalam bentuk sekuler. Mitos, teologi, dan ideologi menyediakan suatu "pedoman" bagi individu dan masyarakat untuk membangun kehidupan yang lebih baik. Kedua, agama membuat keteraturan transendental masyarakat. Semakin komplek masyarakat, diperlukan suatu "nilai suci tertinggi" agar keteraturan sosial terjaga. Ketiga, agama dapat mengembangkan keterikatan emosional atau komitmen sosial. Komitmen berkaitan erat dengan agama, akan membawa kepada kehendak bersama, seperti yang dilakukan oleh sebuah suku bangsa tertentu dalam memperkuat solidaritas sosialnya. Ia menjadi pegangan emosional dalam pemusatan-pemusatan identitas yang serba banyak. Keempat, agama, terutama dalam bentuk ritual, dapat menegakkan nilai kebersamaan. Ritual akan memberikan rasa memiliki dan identitas bagi manusia dalam berkelompok. ${ }^{23}$

Identitas keagamaan menjadi menarik untuk dibincangkan dalam konteks globalisasi. Kata globalisasi berasal dari istilah dalam bahasa Inggris, yaitu globe dan globalization yang berarti dunia atau proses masuknya ke ruang lingkup dunia. ${ }^{24}$ Dalam konteks sosial, globalisasi adalah suatu istilah yang berhubungan dengan era peningkatan ketergantungan antarbangsa dan antarmanusia di seluruh dunia melalui

23 Hans Mol, "Religion and Identity: A Dialectic Interpretation of Religious Phenomena," dalam Hayes, V.C. ed., Identity Issues and World Religions (Bedford Park, Australia: Australian Association for the Study of Religion, 1986), 66-70.

${ }^{24}$ http://www.kbbi.web.id/globalisasi, diakses 2 Desember 2016. 
jalan perdagangan, politik, perjalanan, budaya populer, dan bentukbentuk interaksi sosial lain, sehingga mengakibatkan batas-batas suatu negara dan bangsa menjadi kabur. Globalisasi juga merupakan proses interaksi sosial tanpa adanya batasan jarak yang menjadikan ruang lingkup kehidupan umat manusia semakin bertambah luas, terutama dalam memainkan peranan sosialnya ketika melihat dunia sebagai kesatuan tunggal. ${ }^{25}$

Menurut Roland Robertson, fenomena globalisasi berfokus pada ide tentang glokalisasi, lawan dari globalisasi sebagai sistem dunia. Glokalisasi adalah proses integrasi antara "yang global" dan "yang lokal". Dalam cultural studies, glokalisasi termasuk paradigma hibridisasi budaya yang menekankan keberagaman yang semakin meningkat terkait dengan percampuran unik antara yang global dengan yang lokal. Robertson menjelaskan empat unsur penting dalam globalisasi yang dianut oleh orang-orang yang menekankan glokalisasi: 1) Dunia sedang bertumbuh semakin pluralistik. 2) Individu-individu dan kelompok-kelompok lokal mempunyai kekuasaan besar untuk menyesuaikan diri, memperbaharui, dan melakukan manuver dalam sebuah dunia yang glokal. Teori glokalisasi melihat individu-individu dan kelompok-kelompok sebagai agen yang penting dan kreatif. 3) Proses-proses sosial adalah berhubungan dan saling tergantung. Globalisasi membangkitkan berbagai aksi umpan balik dari kubu nasionalis/etnis sehingga menghasilkan glokalisasi. 4) Komoditas-komoditas dan media, arena dan kekuatan yang merupakan kunci dalam perubahan budaya pada akhir abad ke-20 dan awal abad ke-21 M, tidak dilihat sebagai kekuatan yang memaksa namun lebih sebagai penyedia materi untuk dimanfaatkan dalam kreasi individual dan kolektif di seluruh wilayah dunia yang terglokalisasi. ${ }^{26}$

Robertson menfokuskan analisisnya mengenai globalisasi sebagai fenomena masyarakat dunia yang patut menjadi obyek kajian dalam skala global. Ruang lingkup kajian global itu dapat meliputi ilmu sosial, politik, hubungan internasional, ekonomi maupun budaya yang mempunyai

\footnotetext{
${ }^{25}$ May T. Rudy, Hubungan Internasional Kontemporer dan Masalab-masalab Global (Bandung: Rafika Aditama, 2003), 5.

26 Ashad Kusuma Djaya, Teori-teori Modernitas dan Globalisasi (Yogyakarta: Kreasi Wacana, 2012), 122.
} 
ruang lingkup luas menyangkut proses interaksi sosial dan berbagai koneksi. ${ }^{27}$ Ini artinya dalam konteks glokalisasi, globalisasi juga merupakan pemicu dari menguatnya identitas lokal di ruang-ruang publik yang disebut glocalization. ${ }^{28}$

\section{Komunitas Masjid di Tengah Globalisasi}

Masjid tidak semata-mata tentang sebuah bangunan yang kemudian digunakan oleh orang Islam untuk melaksanakan ibadah, tetapi juga merupakan pengejawantahan simbolisme dari nilai-nilai yang dianut, diyakini, dan dilaksanakan oleh komunitasnya. Untuk memahami simbolisme masjid tersebut, tidak cukup hanya dengan melihat tampilan fisik masjid, tetapi juga perlu meneroka sejarah dan semua aktivitas yang ada di dalamnya. Aspek fisik dan non fisik dari sebuah masjid akan menjadi sumber informasi yang sangat kaya tentang pola keberagamaan dan keyakinannya, struktur sosial, serta corak dan watak masyarakat pendudukungnya.

\section{Masjid Agung Jami' Singaraja Bali: Identitas Islam Bali yang Toleran}

Masjid Agung Jami' Singaraja adalah salah satu masjid tertua di Kabupaten Buleleng, tepatnya di Jalan Imam Bonjol 65 kota Singaraja. Secara administratif, masjid yang dibangun di atas lahan seluas $1980 \mathrm{~m} 2$ dan dikelilingi pagar besi ini berada di Kelurahan Kampung Kajanan, Kecamatan Buleleng, Kabupaten Buleleng, Provinsi Bali. Berada di area masjid Agung Jami' Singaraja akan membuat kita lupa bahwa masjid tersebut berada di Bali, yang seringkali diasosiasikan sebagai kawasan Hindu. Suasana di kawasan Masjid Agung Jami' Singaraja, mirip dengan suasana di Jawa, khususnya Jawa Timur. Laki-laki memaakai sarung

27 Roland Robertson, "Mapping the Global Condition: Globalization as the Global Concept," Sage Journals: Theory, Culture and Society 7, issue 2-3 (June 1990): 20, https://doi.org/10.1177/026327690007002002.

28 Richard Giulianotti and Roland Robertson, "Glocalization, Globalization, and Migration: The Case of Scottish Football Supporters in North America," Sage Journals: International Sociology 21, issue 2 (March 2006): 171-198, https://doi.org/10.1177/0268580906061374. 
dengan berpeci, perempuan berjilbab, dan saat menjelang waktu salat dari pengeras suara masjid terdengar orang ngaji.

Masjid Agung Jami' Singaraja merupakan potret relasi harmonis antara Hindu dan Islam di Kerajaan Buleleng. Masjid ini didirikan pada tahun $1846 \mathrm{M}$ pada masa pemerintahan Raja Buleleng A.A. Ngurah Ketut Jelantik Polong (putra A.A. Panji Sakti, raja Buleleng I). Keberadaan masjid ini merupakan bentuk perhatian dan kepedulian Raja Buleleng yang beragama Hindu kepada umat Islam di daerah tersebut. Raja Buleleng memberikan tanah sebagai tempat pembangunan masjid, mengawal proses pembangunan masjid dengan menugaskan saudaranya bernama A.A. Ngurah Ketut Jelantik Tjelagie ${ }^{29}$ dan Abdullah Maskati yang beragama Islam untuk memimpin pembangunan, memerintahkan juru ukir puri untuk membuat ukiran masjid, dan memberikan kori (gerbang puri) untuk dijadikan gerbang masjid.

Secara keseluruhan, arsitektur Masjid Agung Jami' Singaraja merupakan perpaduan antara spirit Islam dengan arsitektur Bali. Atap Masjid Agung Jami' Singaraja berbentuk limasan dan pada setiap sudut terdapat ukiran cungkup (seperti sulur) enam buah. Pada daun pintu dan jendela terdapat ukiran stilisasi bunga-bunga dengan warna-warna yang cerah, sangat khas Bali.

Secara formal, alasan pembangunan Masjid Agung Jami' Singaraja karena masjid keramat atau masjid tua ${ }^{30}$-masjid pertama di

${ }^{29}$ A. A. Ngurah Ketut Jelantik Tjelagie memiliki peran besar dalam menyebarkan Islam dan membangun kehidupan yang harmoni antara Islam dan tradisi Bali, salah satunya adalah menulis ulang Alquran dengan hiasan motif khas Bali di bagian pinggirnya. Alquran tulisan tangan A.A. Ngurah Ketut Jelantik Tjelagie saat ini tersimpan di Masjid Agung Jami' Singaraja dalam kondisi tidak terawat. Alquran bersejarah tersebut diletakkan dalam kotak kaca terkunci dibagian belakang mimbar tanpa mendapat perawatan yang layak, kelihatan kumal dan lusuh. Hanya diletakkan dalam kotak kaca yang dikunci dengan kunci gembok.

${ }^{30}$ Masjid tua atau masjid keramat ditemukan oleh masyarakat Muslim yang pindah dari pelabuhan Buleleng ke pinggiran Sungai Tukad Mungga pada tahun 1654. Jarak pelabuhan Buleleng ke Sungai Tukad Mungga sekitar 500 meter. Pada saat ditemukan, bangunan segi empat berukuran 15 kali 15 meter persegi tersebut dipenuhi semak belukar dan di dalamnya terdapat sebuah mimbar masjid yang diukir dari ornamen khas Bali. Warga berkesimpulan bangunan ini adalah masjid. Sayangnya, tidak diketahui siapa 
daerah Buleleng-yang berada di jalan Hasanuddin dan berada dipinggir Sungai Tukad Mungga tidak lagi mampu menampung jumlah jamaah yang setiap tahun semakin bertambah. Upaya perluasan masjid keramat juga tidak memungkinkan karena di samping kanan, kiri serta sebelah barat masjid telah dipenuhi rumah-rumah penduduk. Namun, mungkin saja ide pembangunan masjid baru bukan karena alasan formal tersebut, tetapi untuk menghindari pembongkaran masjid bersejarah nan sakral tersebut. $^{31}$

Ritual keagamaan yang dijalankan di Masjid Agung Jami' Singaraja cukup menarik. Sebelum azan masuk waktu salat, dari speaker masjid di putar qiraah selama kurang lebih lima menit. Imam memimpin salat dengan mengeraskan bacaan basmalah dan setelah salam berzikir bersama dengan suara keras, dengan membaca subhanallah, Alhamdulillah, dan Allahuakbar. Selama melakukan penelitian, terdapat fenomena cukup menarik, yaitu ketika Imam salat selalu membaca qunût nẫ̧ilab ${ }^{32}$ dalam setiap salat fard\}. Sebagian besar jamaah mengamini, namun ada juga beberapa jamaah yang diam saja. Menurut salah satu informan, pembacaan qunût tersebut atas instruksi Ketua Takmir, yaitu untuk memohon pertolongan Allah.

yang telah membangunnya. Namun demikian, warga terus berupaya menjaga keaslian bangunan tersebut. Tiga pintu masjid masih terlihat ukiran ormanem khas Bali. Dindingnya berasal dari kapur yang dicampur bebatuan. Terlepas dari siapa saja yang telah membangunnya, keberadaan masjid kuno atau masjid keramat tersebut menunjukkan bahwa kawasan pelabuhan Buleleng merupakan daerah persinggahan para saudagar Muslim. Selain itu, keberadaan masjid tersebut menjadi bukti bahwa di daerah Buleleng pada tahun 1654 telah disinggahi (ditinggali) oleh orang-orang Islam.

${ }^{31}$ Alasan serupa terjadi pada pembangunan Masjid Raya Al Fatah Ambon. Lebih lanjut pembahasan tentang Masjid Raya Al Fatah akan dibahas tersendiri.

${ }^{32}$ Penulis sempat terkejut dengan pembacaan kunut tersebut, namun ternyata pembacaannya bukan sebuah kebetulan, tetapi memang dilakukan dengan sengaja. Berdasarkan pengamatan yang dilakukan selama melakukan penelitian, pembacaan kunut tersebut dilakukan setiap salat, seperti Zuhur, Asar, Magrib dan Isya selalu membaca qunût nâzilah. Menurut Koordinator keagamaan Masjid Agung Jami’ Singaraja, Hariyanto, pembacaan Qunut tersebut atas perintah dari Bapak Takmir, yaitu untuk mendoakan agar bangsa Indonesia, dan khususnya umat Islam senantiasa mendapat pertolongan dari Allah dan dijauhkan dari segala bencana. 
Hari Jumat menjadi salah satu hari yang menarik. Suara speaker yang memperdengarkan pembacaan ayat-ayat suci Alquran terdengar beberapa saat sebelum pelaksananaan salat Jumat. Takmir menyalakan perangkat elektronik untuk menunjang kelancaran salat, seperti microphone dan video shooting. Video digunakan untuk pengambilan gambar dalam bentuk audiovisual khatib yang sedang membaca khutbah Jumat dan Imam yang sedang memimpin salat. Salat Jumat dilakukan dengan azan dua kali, dan khutbahnya disampaikan dengan bahasa Indonesia. Menurut penuturan salah seorang responden, salat tarawih dan witir dalam bulan Ramadan dilaksanakan dalam 23 rakaat, walau ada juga yang hanya sebelas.

\section{Masjid Raya Al Fatah Ambon: Merawat Islam Ambon dari Banjir Bandang Budaya Global}

Masjid Raya Al Fatah Ambon terletak di tengah kota Ambon, berdekatan dengan pasar dan pelabuhan, tepatnya berada di jalan Sultan Babullah, Ambon, Maluku. Masjid ini berada persis di samping Masjid Jami' An-Nur, salah satu masjid tertua di Ambon dan masjid yang dianggap sakral oleh masyarakat setempat. Pada dasarnya pembangunan Masjid Al Fatah merupakan perluasan bangunan dari masjid Jami’ yang sudah tidak lagi menampung jumlah umat Islam yang hendak melaksanakan ibadah.

Posisinya yang berada di tengah kota, masjid ini menjadi tempat strategis dan mudah dijangkau oleh siapa saja yang ingin beribadah atau sekedar melepas lelah. Selepas salat Zuhur misalnya, kita dapat melihat para jamaah yang duduk-duduk di dalam atau emperen masjid, baik sedang ngobrol, atau hanya sekedar memainkan gadget. Halaman masjid yang luas juga cukup memberikan kenyaman kepada siapa saja yang membawa kendaraan, walaupun pada saat pelaksanaan salat Jumat tetap saja tidak muat. Namun demikian, posisinya yang berada di tengah kota dengan akses yang sangat mudah sering kali menjadi persoalan tersendiri, khusunya terkait dengan keamanan. Menyadari keadaan tersebut, pihak pengelola masjid memasang beberapa CCTV di sudut-sudut masjid. Selain itu, ketika jam kerja, khsusnya pagi sampai siang hari, semua pintu gerbang ditutup dan dikunci. Jika tetap ingin masuk harus ijin terlebih dahulu kepada satpam. 
Peletakan batu pertama pembangunan masjid ini dilakukan oleh Presiden Republik Indonesia Dr. Ir. Soekarno pada tanggal 1 Mei 1963, dan diberi nama Masjid Raya Al Fatah. Nama Al Fatah yang berarti "kemenangan", ditamsilkan dari peristiwa kembalinya Irian Barat dalam pangkuan Ibu Pertiwi, buah usaha final Trikora, pimpinan Jenderal Soeharto. Pada tahun 1984, Masjid Raya Al Fatah diresmikan pemakaiannya oleh Menteri Agama Republik Indonesia. Selanjutnya, dalam rangka menyambut dan mensukseskan MTQ Nasional ke 24 di kota Ambon, pada tahun 2010 Masjid Raya Al Fatah direnovasi.

Keberadaan Masjid Al Fatah Ambon sangat penting tidak saja karena sebagai pusat penyiaran agama Islam, tetapi juga peran positifnya terutama ketika meledak konflik Ambon pada tahun 1999 silam. Masjid ini menjadi tempat pengungsian masyarakat Muslim yang bertempat tinggal di Ambon. Selain itu, masjid ini juga menjadi rumah dan benteng bagi Islam Ambon yang toleran dan akomodatif terhadap budaya lokal dari pengaruh faham keislaman yang cenderung keras dan intoleran.

Masjid Raya Al Fatah merupakan pengejawantahan dari Islam Ambon yang ramah dan toleran terhadap budaya lokal dan penganut agama lain. Masjid Al Fatah adalah identitas komunitas Islam Ambon. Secara organisasi, Islam yang dijalankan di Masjid Al Fatah Ambon tidak berafiliasi dengan organisasi apapun, seperti NU dan Muhammadiyah. Secara ritual keagamaan menjalankan Islam Ahl al-Sunnah wa al-Jamâ'ah. Setelah salat lima waktu jamaah melakukan zikir bersama, membaca qunût setiap salat Subuh, azan dua kali saat salat Jumat, dan ada pembacaan tarbjim sebagai penanda waktu salat sebelum dikumandangkannya adzan. Demikian disampaikan oleh salah satu penghulu masjid, ustaz Nashir Rahawarin, ketika ditanyakan Islam apakah yang dijalankan di Masjid $\mathrm{Al}$ Fatah Ambon.

Berdasarkan pengamatan yang kami lakukan selama berada di Ambon, yang disampaikan oleh ustaz Nashir Rahawarin adalah benar adanya. Dalam setiap salat jamaah yang dilakukan, selalu diakhiri dengan zikir bersama membaca Istighfâr, Subh\}ân Allah, al-H\{amd li Allâh, dan Allâh Akbar secara nyaring dan berulang-ulang, serta diakhiri dengan doa bersama yang dipimpin oleh Imam. Untuk salat-salat berjamaah yang 
memungkinkan pembacaan al-fatihah dan surat-surat pendek secara nyaring, Imam selalu membaca basmalaah diawal bacaan surat.

\section{Masjid Saka Tunggal Banyumas: Identitas Komunitas Islam Jawa}

Masjid Masjid Saka Tunggal Baitussalam atau lebih dikenal dengan Masjid Saka Tunggal, terletak di Desa Cikakak, Kecamatan Wangon, Banyumas, Kabupaten Banyumas, Provinsi Jawa Tengah. Masjid ini dianggap sebagai masjid tertua di Indonesia, karena menurut tahun yang tertera pada saka tunggalnya, masjid ini dibangun pada tahun 1288 Masehi oleh Mbah Mustholeh yang dimakamkan di atas bukit disebelah barat Masjid Saka Tunggal. Jika dilihat dari angka tahun pendiriannya-pada tahun $1288 \mathrm{M}$ (abad ke-12)-masjid ini merupakan satu-satunya masjid tertua di pulau Jawa yang dibangun sebelum masa dakwah Walisongo. Ini berarti, masjid ini telah ada 2 abad sebelum era Walisongo hidup pada masa abad 15-16 Masehi, dan bahkan lebih dahulu ada dari kerajaan Majapahit.

Masyarakat Banyumas secara konvensional menyebutnya sebagai Masjid Saka Tunggal. Penyebutan ini berhubungan dengan konstruksi masjid yang dibangun dengan satu pilar utama (tiang penyangga tunggal) yang berada di tengah masjid. Pilar utama ini memiliki empat sayap sebagai penopang bangunan atap masjid. Tiang dengan empat sayap penopang yang berada di tengah masjid ini terlihat seperti sebuah totem. Pada bagian bawah tiang terdapat kaca pelapis yang berfungsi untuk melindungi bagian yang terdapat tulisan tahun pendirian masjid tersebut. Tiang masjid ini berdiri menjulang hingga bagian wuwungan yang berbentuk limas. Bentuk limas ini sama dengan bentuk wunungan Masjid Agung Demak.

Letak masjid berada tepat di kaki gunung Cikakak, dan relatif jauh dari jalan raya. Untuk sampai ke lokasi harus melewati jalan kampung beraspal yang tidak terlalu bagus, namun diujung jalan sudah tersedia lapangan parkir untuk kendaraan peziarah dan/atau wisatawan ke Masjid Saka Tunggal. Untuk sampai dilokasi masjid, kita harus melewati pintu gerbang dengan membayar karcis. Lokasi masjid berada tepat diujung jalan di bawah gunung Cikakak. Di sekitar masjid hanya ada 
tiga rumah yang ditempati oleh keturunan pendiri Masjid Saka Tunggal Mbah Mustholeh yang sekaligus berperan sebagai juru kunci masjid.

Jika malam menjelang, suasana di sekitar Masjid Saka Tunggal sangat lengang. Hanya beberapa lampu kecil yang menerangi. Hampir tidak ada kehidupan sama sekali, terutama selepas salat Isya. Suasana nampak sangat berbeda pada pagi dan siang hari. Kawanan kera yang jumlah sangat banyak akan memenuhi sekitar wilayah masjid. Kera-kera tersebut turun dari bukit yang berada di sebelah barat Masjid Saka Tunggal.

Ada empat sayap yang menopang di bagian tiang Masjid Saka Tunggal tersebut. Dari model arsitektur seperti itu tidak terlepas dari filosofi yang dikandung di dalamnya, yaitu papat kiblat lima pancer atau empat mata angin dan satu pusat. Empat kiblat berarti manusia sebagai pusat pusaran dikelilingi oleh empat mata angina: api, angin, air, dan bumi. Dari empat penjuru mata angin ini, manusia sebagai makhluk hidup harus mampu menciptakan keseimbangan. Sementara tiang tunggal itu merupakan simbol bahwa manusia seyogyanya seperti huruf alif, tidak bengkok. Manusia yang tidak bengkok artinya tidak boleh bengkok, tidak nakal dan tidak berbohong. Ada sebuah kontrol serta pernyataan yang bersifat sanksi dari ajaran ini, yaitu apabila manusia bengkok, maka tidak layak disebut manusia.

Adapun filosofi keseimbangan dari empat penjuru mata angin adalah ajaran untuk tidak berlebihan dalam penggunaan air agar tidak tenggelam, jangan banyak bermain angin bila tak ingin masuk angin, jangan berlebihan bermain api agar tidak terbakar dan jangan berlebihan memuja bumi agar tidak terjatuh. Empat mata angin dan satu penjuru tersebut juga mempunyai rujukan makna pada terminlogi Islam Jawa yang disebut aluamah, mutmainah, sopiah, dan amarah, yaitu empat nafsu yang selalu bertarung dan memengaruhi watak manusia. ${ }^{33}$

\footnotetext{
33 Teguh Trianton, "Fungsi Antropologi Masjid Saka Tunggal: Studi Etnografi Pada Umat Islam Aboge Banyumas," dalam Research Gate (Juni 2014): 5, dipublikasi Juni 2014, diakses 8 Desember 2016, https://www.researchgate.net/ publication/312494357_Fungsi_Antropologis_Masjid_Saka_Tunggal_Studi_Etnografi_ Pada_Umat_Islam_Aboge_Banyumas
} 
Komunitas Masjid Saka Tunggal berada di bawah gunung Cikakak dan menganut tradisi budaya Islam Aboge. Aboge merupakan singkatan dari Alif-Rebo-Wage, yaitu sebuah sistem perhitungan kalender yang menggabungkan kalender winduan dengan beberapa jumlah perhitungan hari pasaran dalam tradisi Jawa: Pon, Wage, Kliwon, Legi, dan Pabing. Jika dirunut dari sisi historis, perhitungan sistem Aboge ini dimulai dari perintah Sutan Agung Hanyakrakusuma sebagai pemegang kekuasaan tertinggi di Kerajaan Mataram pada saat itu. Sistem penaggalan ala Aboge mengisyaratkan kepastian waktu jatuhnya hari Idul Adha, Idul Fitri, dan permulaan Ramadan. ${ }^{34}$ Dalam kepercayaan Aboge, salat Idul Fitri disebut dengan Shalat Ngiqti (Iqti) dilaksanakan setelah puasa Syawal pada tanggal 8 bulan Syawal pada pagi hari, dan ada pula salat Rebo Wekasan yang dilaksanakan pada hari rabu terakhir pada bulan Safar. ${ }^{35}$

Ritual keagamaan yang dilaksanakan di Masjid Saka Tunggal cukup unik. Dalam salat Magrib misalnya, mereka memulai kegiatan ibadah dengan menabuh bedug dan kentongan yang dilakukan oleh juru kunci dan dilanjutkan dengan azan langgam Jawa. Setiap orang yang datang melaksanakan salat sunah yang jumlahnya sekitar empat salam masing-masing dua rakaat. Setelah melaksanakan salat sunah, sambil menunggu Imam, jamaah salat Magrib membaca syiiran yang lafalnya campuran antara bahasa Arab dan bahasa Jawa yang dilagukan seperti orang bergumam. Bagi mereka yang tidak terbiasa dengan bahasa Jawa ngapak, sangat sulit untuk memahami rangkaian syïran yang dibaca.

Bedug kembali ditabuh sebagai tanda akan segera dilaksanakannya salat Magrib. Imam berdiri dan salah satu jamaah membaca iqâmah. Ketika membaca surat al-Fâtih $\}$ ah dan surat Alquran, Imam membacanya dengan cepat dan cenderung seperti orang bergumam. Bagi mereka yang terbiasa membaca Alquran dengan tartil akan merasa janggal dengan cara membacanya. Gerakan-gerakan salat

\footnotetext{
34 Sulaiman. "Islam Aboge: Pelestarian Nilai-nilai Lama di Tengah Perubahan Sosial," Analisa: Journal of Social Science and Religion 20, no. 1 (Juni 2013): 9.

35 Joko Tri Haryanto, "Relasi Agama dan Budaya dalam Hubungan Intern Umat Islam," Jurnal SMaRT 1, no. 1(Juni 2015): 44.
} 
juga cenderung cepat, namun para jamaah yang sebagian besar sudah berusia lanjut dapat mengikutinya. Setelah salam, dilanjutkan dengan pembacaan zikir. Lagi-lagi dengan pelafalan yang cenderung bergumam. Bacaan yang cukup menarik dan mudah diterka adalah pembacaan kalimat Lâ ilâh illâ Allâh yang dalam jumlah hitungan tertentu berubah menjadi illâ Allâh, bu Allâh, dan bu'. Setelah selesai wiridan, Imam memimpin para jamaah untuk melaksanakan salat sunah yang jumlahnya sekitar 10 salam, di mana masing-masing salam berjumlah dua rakaat. Setelah selesai melaksanakan salat sunah tersebut, dilanjutkan dengan pelaksanaan salat Isya secara berjamaah. Rangkaiannya pun dan ritual yang dilakukan sama dengan pelaksanaan salat magrib. Ada kejadian unik pada saat zikir setelah salat Isya, di mana salah satu jamaah mematikan semua lampu dan menutup pintu masjid. Setelah selesai zikir, lampu kembali dihidupkan dan pintu masjid dibuka lagi.

Pelaksanaan salat Jumat juga cukup unik. Tidak ada pengeras suara, hanya beduk yang ditabuh oleh juru kunci: tidak terus-terusan, tetapi ada jedanya. Sambil menunggu waktu salat Jumat, jamaah melaksanakan salat sunah dan melantukan syïran berbahasa Arab yang bercampur dengan bahasa Jawa Banyumasan. Azan pertama dilakukan oleh empat orang memakai jubah berwarna putih dan menutup kepalanya dengan udeng batik warna biru, dengan menggunakan langgam Jawa. Unik dan sangat indah. Hal unik lainnya adalah ketika khatib naik ke atas mimbar. Sang khatib ketika membacakan khutbahnya yang berbahasa Arab walau hanya terdengar sekilas berada dibalik tirai. Dengan berada dibalik tirai tersebut, para jamaah tidak dapat melihatnya.

Keunikan lainnya dapat dilihat saat pelaksanaan salat Jumat, zikir setelah salat, dan pelaksanaan salat sunah yang jumlahnya sekitar sepuluh salam, di mana setiap salam terdiri dari dua rakaat. Setelah selesai melaksanakan rangkaian ritual salat Jumat tersebut, para jamaah tidak langsung pulang, tetapi ada yang bergeser ke belakang lalu ndeprok dalam posisi sujud, seperti menyembah sesuatu. Setelah itu baru para jamaah meninggalkan masjid. 


\section{Komunitas Masjid Merespon Globalisasi}

Dunia global tidak semata-mata proses homogenisasi budaya, tetapi juga memberi peluang bagi terjadinya kehidupan dunia yang semakin heteregon, pluralistik. Individu-individu dan komunitaskomunitas-bahkan yang marginal sekalipun-memiliki ruang dan kesempatan yang sama dengan kelompok dominan untuk melakukan adaptasi, eksplorasi nilai-nilai diri, dan manuver dalam arena globalisasi. Individu dan komunitas-komunitas lokal bukan benda mati yang hanya bisa menerima dan mengikuti stimulus yang datang dari luar, tetapi adalah agen penting dan kreatif, yang mampu untuk memilah dan memilih apa unsur-unsur luar yang dapat diterima, diadaptasi, dan apa yang harus ditolak sesuai dengan kebutuhan dan kerentanan identitasnya. Komunitas-komunitas masjid tersebut tentu-meminjam teori Michel de Certeau dalam bukunya the Practice of Every Day Life (1984)—memiliki taktik untuk merespon strategi kooptasi budaya global.

\section{Komunitas Masjid ditengah Budaya Global}

Masjid merupakan simbol identitas bagi komunitasnya. Dengan kata lain, masjid merupakan pengejawantahan dari identitas komunitasnya. Masjid Saka Tunggal yang menjadi identitas komunitas Islam Jawa yang dikenal orang sebagai Islam Aboge. Masyarakat umum hanya mengenal Islam Aboge sebagai Islam yang menjalankan ibadah puasa Ramadan, salat Idul Fitri, dan salat Idul Adha cenderung berbeda dari kebanyakan pemeluk agama Islam di Indonesia. Ketika pemerintah Indonesia melalui kementerian Agama dan kelompok-kelompok Islam di Indonesia sibuk mengadakan sidang isbat awal Ramadan dan Hari Raya, mereka tidak peduli. Jika menurut mereka sudah waktu puasa, salat Idul Fitri, dan salat Idul Adha berdasarkan hitungan yang diwariskan oleh leluhur mereka_disebut aboge atau alif rabo wage-, mereka akan melaksakan puasa, salat Idul Fitri dan/atau salat Idul Adha, tidak peduli apakah sesuai dengan keputusan pemerintah atau tidak.

Masjid Saka Tunggal Cikakak berada cukup terpencil, persis dikaki sebuah gunung dengan jalan akses yang relatif sulit, namun cukup dikenal oleh masyarakat Indonesia, khususnya menjelang pelaksanaan salat Idul Fitri dan Idul Adha. Pada dua momentum tersebut, beberapa 
media baik televisi maupun media cetak dan online berdatangan untuk melihat, meliput, dan mengabarkan kepada dunia bahwa di sebuah tempat terpencil ada penganut Islam yang melaksanakan Idul Fitri dan Idul Adha pada waktu yang berbeda dari waktu yang ditetapkan oleh pemerintah. Bahkan, mereka melaksanakannya ketika pemerintah masih berdebat hangat untuk menentukan kapan waktunya. Namun walaupun menjadi buah mata mass media, mereka seolah-olah tidak ambil pusing.

Melongok ke dalam Masjid Saka Tunggal, kita akan mengetahui identitas komunitas Masjid Saka Tunggal Cikakak yang khas dan unik. Mereka menjalankan ritual keagamaan sebagai orang-orang Islam Jawa, yaitu Islam yang sangat menghargai dan menghormati leluhur, dengan teguh dan tawaduk. Di tengah hiruk pikuk Arabisasi dan purifikasi keislaman yang digelorakan oleh mass media, khususnya televisi dan media cetak, mereka tetap secara teguh menjalankan ajaran agama Islam sebagaimana diajarkan oleh leluhur mereka. Membaca surat-surat Alquran dalam salat dengan langgam Jawa dan dialek ngapak, sehingga terdengar samar-samar dan terasa tidak sesuai dengan kaidah-kaidah membaca Alquran, sering kali akan mengundang orang nonkomunitas Saka Tunggal (non-Islam Aboge) untuk menyalahkan mereka. Namun kekhususan mereka untuk berzikir setelah salat fardu (wajib), melaksanakan ragam salat sunah setelah salat wajib hingga puluhan salam dengan dua rakaat, tradisi salaman setelah salat atarjamaah, dan diakhiri dengan sujud syukur menunjukkan betapa agamisnya mereka. Nampaknya tidak salah jika kita berkesimpulan bahwa hidup mereka hanya untuk beribadah kepada sang Maha Pencipta. Globalisasi dengan segala pernak-pernik nilai yang dibawanya seolah-olah berhenti di pintu masuk Masjid Saka Tunggal.

Masjid sebagai simbol identitas dari komunitas pendukungnya juga dapat dilihat dari keberadaan Masjid Agung Jami' Singaraja sebagai representasi identitas Islam Bali dan Masjid Al Fatah Ambon yang merupakan representasi dari identitas komunitas Islam Ambon. Namun berbeda dengan Masjid Saka Tunggal Cikakak Banyumas, Masjid Agung Jami' Singaraja cenderung akomodatif dengan globalisasi dan nilai-nilai yang dibawanya. Kedua masjid ini memanfaatkan secara kreatif dan selektif teknologi modern sesuai dengan kebutuhannya. CCTV yang 
dipasang hampir di setiap pojok masjid. Masjid yang luas dan posisinya yang terletak di tengah kota dan/atau pinggir jalan raya, maka penggunaan CCTV merupakan kebutuhan untuk menjamin kemananan fasilitas masjid dan kenyaman para jamaah. "Dengan CCTV ini, kami dapat mengawasi semua bagian masjid dari ruangan ini. Salah satu persitiwa yang mendasari dipasangnya CCTV ini adalah seringnya kehilangan sandal para jamaah, khusunya saat salat Jumat," ungakp Hariyanto, salah satu Takmir Masjid Agung Jami' Singaraja.

Selain CCTV, di Masjid Al Fatah Ambon dan Masjid Agung Jami' Singaraja juga terdapat vidio shooting yang digunakan setiap salat Jumat, yaitu untuk digunakan untuk pengambilan gambar dalam bentuk audiovisual khatib yang sedang menyampikan khutbah dan Imam yang sedang mengimami salat Jumat, dan relay melalui televisi yang berada di beberapa tempat dalam masjid. Dengan cara ini, para jamaah salat Jumat dan melihat khatib dan imamnya. Khusus untuk Masjid Al Fatah Ambon, penyebaran materi khutbah juga dilakukan dengan siaran langsung RRI Ambon. Teknologi dimanfaatkan oleh komunitas Masjid Al Fatah Ambon dan Masjid Agung Jami' Singaraja untuk "mengomunikasikan" identitas komunitasnya.

Nilai-nilai modern juga digunakan oleh komunitas Masjid $\mathrm{Al}$ Fatah Ambon dan Masjid Agung Jami' Singaraja untuk melakukan transparansi dan akuntabilitas pengelolaan masjid. Setiap Jumat, selalu dilaporkan sirkulasi keuangan yang didapat dari infak jamaah dan/atau donasi lainnya, termasuk juga penggunaannya. Jamaah juga mendapatkan informasi siapa yang akan menjadi imam dan khatib salat Jumat, imam salat fardu, pengisi pengajian rutin, dan kegiatan-kegiatan lain yang akan dilaksanakan. Namun demikian, bukan berarti modernitas dapat masuk ke masjid secara leluasa, tetapi ada pembatasan sedemikian rupa, misalnya ketika waktu salat atau masuk masjid HP, harus dimatikan atau silent. Seolah-olah ada ruang yang jelas antara ruang agama dan ruang dari modernitas. Namun demikian, tidak sedikit yang masih memainkan HP saat khatib sedang menyampaikan khutbahnya.

Jika melihat latar depan-tampilan arsitektur dan kelengkapan masjid-kita menemukan akomodasi selektif terhadap modernitas, maka pada latarbelakangnya-nilai interiksinya-kita akan menemukan 
kecenderungan untuk secara tegas menjaga identitasnya, yaitu sebagai represantasi dari identitas komunitas Islam yang ramah terhadap budaya lokal, dan toleransi positif terhadap keberadaan agama lain. Masjid Al Fatah Ambon merupakan representasi dari identitas komunitas Islam Ambon yang ramah dan toleran terhadap budaya lokal, demikian pula dengan Masjid Agung Jami' Singaraja yang merupakan identitas dari komunitas Islam Bali yang ramah dan toleran terhadap budaya lokal.

\section{Agen dalam Pertahanan Identitas}

Globalisasi memberikan peluang yang besar bagi komunitas lokal untuk melakukan aktualisasi diri secara kreatif sesuai dengan kemampuan, kebutuhan, dan tujuannya. Sebagaimana telah dibahas sebelumnya, komunitas tiga masjid: Masjid Saka Tunggal Cikakak, Masjid Al Fatah Ambon, dan Masjid Agung Jami' Singaraja Bali secara kreatif mampu mempertahankan identitasnya di tengah banjir bandang budaya global. Salah satu faktornya adalah keberadaan pemimpin ketiga komunitas masjid tersebut.

Pemimpin Masjid Saka Tunggal Cikakak lebih dikenal dengan sebutan juru kunci. Posisi juru kunci sangat penting dalam semua segmen kehidupan masyarakat komunitas Islam Masjid Saka Tunggal (Islam Aboge). Semua ritual keagamaan yang dilaksanakan di Masjid Saka Tunggal di pimpin oleh para juru kunci. Sebagai keturunan Mbah Mustholih, juru kunci juga menjadi mediator masyarakat untuk ngalap berkah dari Mbah Mustoleh. Siapapun yang hendak berziarah dan/atau ngalap berkah harus didampingi oleh juru kunci. Selain itu, sebagai representasi Mbah Mustoleh, mereka memiliki legitismasi untuk "mengatur" masyarakat. Apapun yang dikatakan oleh juru kunci, masyarakat akan mengikutinya, bahkan tanpa bertanya sama sekali. Dalam konteks globalisasi, keberadaan juru kunci menjadi sangat penting. Dia memiliki "wewenang" sangat besar untuk menggerakkan komunitasnya, menerima atau menolak globalisasi. Penerimaan dan/atau penolakan atas globalisasi yang dilakukan oleh juru kunci akan diikuti oleh komunitasnya tanpa bertanya. Menolak atau melawan juru kunci sama halnya menolak dan melawan Mbah Mustoleh. 
Aktor di Masjid Raya Al Fatah Ambon adalah bapak Imam. Bapak Imam memiliki peran sangat penting dalam menentukan warna dan corak keberagamaan komunitas Masjid Al Fatah. Semua keputusan terkait dengan keberagamaan masjid sepenuhnya ditentukan bapak Imam, mulai dari menentukan Khatib Jumat, pengisi pengajian rutin setelah Magrib, dan bahkan pengajian anak-anak. Tanpa persetujuan bapak Imam, siapapun tidak mungkin dapat memimpin kegiatan ibadah di Masjid Raya Al Fatah Ambon. Dalam konteks globalisasi, peran bapak Imam sangat penting untuk menjaga identitas komunitas.

Aktor di Masjid Agung Jami’ Singaraja adalah Ketua Takmir. Peran Ketua Takmir di Masjid Agung Jami’ Singaraja relatif sama dengan penghulu di Masjid Raya Al Fatah Ambon. Ketua takmir memiliki otoritas mutlak untuk mengelola masjid, seperti menentukan siapa-siapa yang boleh menjadi imam salat, khatib Jumat dan penceramah pengajian.

\section{Proses Menegubkan Identitas Komunitas di Tengah Globalisasi}

Agama seringkali berada pada posisi berhadapan dengan globalisasi, namun celakanya globalisasi sendiri merupakan keniscayaan sejarah yang tidak mungkin dibendung oleh agama sekalipun. Oleh karenanya, yang dapat dilakukan oleh komunitas masjid bukan melawannya, tetapi menyikapinya dan memanfaatkan globalisasi untuk memperkuat identitasnya. Ketiga komunitas masjid tersebut secara cerdas melakukan respon terhadap globalisasi: membiarkannya sebagaimana dilakukan komunitas Masjid Saka Tunggal, dan memanfaatkannya sebagaimana dilakukan oleh komunitas Masjid Raya Al Fatah Ambon dan Masjid Agung Jami' Singaraja. Secara garis besar, ada tiga proses yang dilakukan untuk menjaga identitasnya. Pertama, pembiasaan dan pelembagaan. Identitas disosialisasikan dan diinternalisasikan melalui pembiasaan dan pelembagaan, misalnya setelah salat melakukan zikir bersama, azan dua kali pada salat Jumat, dan lain sebagainya. Dengan cara ini, akan terjadi proses internalisasi nilai-nilai yang pada akhirnya akan memperkuat identitas komunitas. Kedua, peneguhan otoritas leluhur. Salah satu cara efektif untuk "melawan" strategi kooptasi globalisasi adalah dengan taktik meneguhkan otoritas leluhur. Hal ini sebagimana dilakukan oleh komunitas Islam Aboge Masjid 
Saka Tunggal Cikakak Banyumas. Mereka membentengi dirinya dengan menyandarkan diri kepada leluhur, yaitu dengan mematuhi dan menjalankan ajarannya. "Anane awake dewe iku kerono anane lelubur, lab kalo ora taat marang lelubur terus awak dewe iki disebut opo?' ungkap salah satu narasumber. Mereka harus menjalankan semua yang telah dijalankan dan diajarkan oleh leluhur dalam kehidupan sehari-hari, jika tidak maka akan kuwalat. Konsep kuwalat menjadi taktik jitu untuk menyikapi globalisasi. Dengan alasan takut kunvalat, komunitas Masjid Saka Tunggal terus mempertahankan ajaran leluhurnya. Ketiga, penguatan visi misi kelembagaan. Keberadaan visi misi lembaga relatif efektif untuk membendung banjir bandang globalisasi, sebagaimana dapat dilihat pada apa yang dilakukan oleh komunitas Masjid Raya Al Fatah Ambon dan Masjid Agung Jami' Singaraja untuk menjaga identitas komunitasnya. Visi misi lembaga menjadi dasar untuk menentukan siapa dan seperti apa khatib dan penceramah yang boleh tampil di Masjid Raya Al Fatah Ambon dan Masjid Agung Jami’ Singaraja.

Kemampuan ketiga komunitas tersebut mempertahankan diri menunjukkan bahwa globalisasi tidak semata-mata menciptakan homogenisasi budaya, tetapi memfasilitasi terciptanya pluralitas budaya. Globalisasi merupakan ruang besar yang disediakan untuk semua kebudayaan-termasuk komunitas agama-untuk bertemu, tampil, bernegosiasi, dan berkontestasi untuk menujukkan eksistensinya. Komunitas masjid bukan benda mati yang tidak berdaya menyikapi apapun yang terjadi pada dirinya, tetapi makhluk kreatif yang dapat memilah dan memilih bagian-bagian dari globalisasi yang dapat digunakan untuk memperkuat dirinya atau harus ditolak karena bertentangan dengan identitas komunitasnya. Globalisasi adalah ancaman pada satu pihak dan peluang pada pihak yang lain. Komunitas Masjid Raya Al Fatah Ambon, Masjid Agung Jami' Singaraja, dan Masjid Saka Tunggal Cikakak Banyumas mengajarkan kepada kita bagaimana memanfaatkan globalisasi untuk memperkuat identitas komunitasnya. Komunitas masjid tersebut ibarat ikan yang berenang di lautan. Walaupun memanfaatkan lautan untuk tempat hidup dan meneruskan transmisi kehidupannya, ikan itu sendiri tidak menjadi asin. 


\section{Penutup}

Globalisasi adalah kenyataan yang harus diterima, dihadapi, dan disikapi oleh siapa saja, termasuk komunitas masjid. Globalisasi meniscayakan tatanan dunia baru yang disebut kampung global, yaitu dunia yang tidak lagi dibatasi oleh sekat-sekat agama, suku bangsa, administrasi negara, dan aliran politik. Situasi ini seringkali diangap sebagai ancaman bagi identitas karena mendorong terjadinya homogenisasi budaya. Padahal, jika melihat fenomena Masjid Saka Tunggal Cikakak, Masjid Al Fatah Ambon, dan Masjid Agung Jami' Singaraja akan ditemukan betapa globalisasi malah memperkuat identitas komunitas. Malahan, identitas komunitas masjid menjadi jangkar bagi identitas individu. Globalisasi memberi ruang kepada setiap individu untuk membangun identitasnya secara bebas sesuai dengan keinginannya. Namun dalam kondisi demikian, individu dapat terjebak dalam situasi tanpa identitas sehingga akan kesulitan dalam mengidentifikasi diri dan memaknai hidupnya.

Masjid Agung Jami’ Singaraja merupakan identitas dari komunitas Islam Bali, Masjid Raya Al Fatah Ambon merupakan identitas dari komunitas Islam Ambon, dan Masjid Saka Tunggal Cikakak merupakan identitas dari komunitas Islam Jawa atau yang dikenal dengan Islam Aboge (Alif Rabo Wage). Dalam konteks globalisasi, individuindividu anggota komunitas masjid tersebut dapat menyerap nilai-nilai dari mana saja, namun ketika masuk ke dalam masjid individu-individu tersebut harus menyesuaikan diri dengan identitas komunitasnya. Identitas komunitas merupakan collective awareness untuk merespon dan menjalani kehidupan di tengah samudra budaya global yang semakin tak terkendali.

Fenomena yang terjadi di Masjid Saka Tunggal Cikakak, Masjid Al Fatah Ambon, dan Masjid Agung Jami' Singaraja menunjukkan bahwa komunitas-komunitas tersebut tidak hanyut oleh banjir bandang globalisasi. Komunitas masjid bukanlah sekumpulan benda mati yang hanya bisa pasrah menerima pengaruh luar, tetapi sekumpulan makhluk hidup yang memiliki otoritas untuk bersikap, yaitu untuk memilah, memilih, dan sekaligus menyikapi setiap nilai-nilai yang datang dari luar diri dan komunitasnya. Mereka memiliki-meminjam bahasa De Certeau 
(1984)—taktik untuk merespon startegi budaya global. Seperti ikan di lautan, hidup dan berenang di dalamnya namun tidak menjadi asin.

\section{Daftar Pustaka}

Azizy, A. Qodri. Melawan Globalisasi: Reinterpretasi Ajaran Islam. Yogyakarta: Pustaka Pelajar, 2004.

Chakim, Sulkhan. "Estetika, Masjid, dan Dakwah." Ibda': Jumal Studi Islam dan Budaya 3, no. 3 (Juli-Desember 2005): 1-9.

Dawa, Markus Dominggus Lere. Teori-teori Sosial tentang Identitas. Makalah Program Doktor Sosiologi Agama UKSW Salatiga, 2011.

Djaya, Ashad Kusuma. Teori-teori Modernitas dan Globalisasi. Yogyakarta: Kreasi Wacana, 2012.

Firmanzah. Globalisasi: Sebuah Proses Dialektika Sistemik. Jakarta: The Ary Suta Center, 2007.

Giulianotti, Richard, and Roland Robertson. "Glocalization, Globalization and Migration: The Case of Scottish Football Supporters in North America." Sage Journals: International Sociology 21, issue 2 (March 2006): 171-198, https://doi.org/10.1177/0268580906061374.

Haryanto, Joko Tri. "Relasi Agama dan Budaya dalam Hubungan Intern Umat Islam.” Jurnal SMaRT 1, no. 1( Juni 2015).

Jameson, Fredric and Masao Miyoshi (eds.). The Culture of Globalization. USA: Duke University Press, 2004.

Madjid, M. Nurcholis. Islam Agama Kemanusiaan. Jakarta: Paramadina, 1995.

Mol, Hans. "Religion and Identity: A Dialectic Interpretation of Religious Phenomena." Dalam Identity Issues and World Religions, ed. Hayes, V.C. Bedford Park, Australia: Australian Association for the Study of Religion, 1986. 
Mu'tasin, Radjasa (ed.). Model-Model Penelitian dalam Studi Keislaman. Yogyakarta: Lembaga Penelitian UIN Sunan Kalijaga, 2006.

Mulyana, Deddy. Metodologi Penelitian Kualitatif. Bandung: Remaja Rosdakarya, 2010.

Pinem, Masmedia. "Masjid Pulo Kameng Akulturasi dan Toleransi Masyarakat Aceh.” Analisa 20, no. 1 (Januari-Juni 2013): 87-97.

Priyanto, Supriyo. Konservasi dan Pengembangan Masjid Agung Kauman Semarang untuk Identitas Budaya dan Pariwisata. Semarang: Departemen Pendidikan Nasional Universitas Diponegoro, 2000.

Purwanto. "Peranan Keberadaan Masjid Agung Demak dalam Perkembangan Kehidupan Sosial Ekonomi dan Budaya Masyarakat Kelurahan Bintoro Kecamatan Demak Kabupaten Demak.” Dimensi 2, no. 1 (November 2014).

Putra, Idham. "Teori Identitas Sosial." Diposting 21 0ktober 2008, diakses 4 April 2015, https://.coidhamputra.wordpressm/2008/10/21/teori-identitassosial/

Putrie, Yulia Eka. "Kontradiksi Simbol dan Substansi Nilai Islam dalam Arsitek Masjid." El-Qudwah: Jurnal Penelitian Integrasi Sains dan Islam 4 (2010).

Ritzer, George, and Dougles J. Goodman. Teori Sosiologi Modern, terj. Alimandan. Jakarta: Prenada Media Group, 2004.

Robertson, Roland. "Mapping the Global Condition: Globalization as the Global Concept." Sage Journals: Theory, Culture and Society 7, issue 2-3 (June 1990): https://doi.org/10.1177/026327690007002002.

Rudy, May T. Hubungan Internasional Kontemporer dan Masalah-masalab Global. Bandung: Rafika Aditama, 2003.

Saleh, Badrus. "Conflict, Jihad, and Religious Identity in Maluku, Eastern Indonesia." Al-Jamiab: Journal of Islamic Studies 46, no. 1 (2008), https://doi.org/10.14421/ajis.2008.461.71-99. 
Salehudin, Ahmad. Satu Dusun Tiga Masjid: Anomali Ideologisasi Agama dalam Agama. Yogyakarta: Pilar Media, 2007.

Secretariat, AsiaDHRRA. The Impact Globalization on the Social-Cultural Live of Grassroots People in Asia. Jakarta: Grasindo, 1998.

Sinaga, Martin Lukito. Identitas Poskolonial Gereja Suku dalam Masyarakat Sipil. Yogyakarta: LKiS, 2004.

Singgih, E. Gerrit. "Globalisasi dan Kontekstualisasi: Menuju Sebuah Kesadaran Baru Mengenai Realitas di Sekitar Kita." Renai: Jurnal Politik Lokal dan Sosial-Humaniora 2, no. 34, (2002).

Sulaiman. "Islam Aboge: Pelestarian Nilai-nilai Lama di Tengah Perubahan Sosial." Analisa: Journal of Social Science and Religion 20, no. 1 (Juni 2013): 1-12.

Trianton, Teguh. "Fungsi Antropologi Masjid Saka Tunggal: Studi Etnografi Pada Umat Islam Aboge Banyumas." Dalam Research Gate (Juni 2014): 5, dipublikasi Juni 2014, diakses 8 Desember 2016, https://www.researchgate.net/publication/312494357_Fungsi_ Antropologis_Masjid_Saka_Tunggal_Studi_Etnografi_Pada_Um at_Islam_Aboge_Banyumas.

Wildan, Muhammad. "Mapping Radical Islamism in Solo: A Study of the Proliferation of Radicalism in Central Java." Al-Jamiah: Journal of Islamic Studies 46, no. 1 (2008): 36-69.

Wolf, Martin. Globalisasi Jalan Menuju Kesejabteraan, terj. Samsudin Berlian. Jakarta: Yayasan Obor Indonesia, 2007.

Zuhdi, Muhammad Harfin. "Radicalism and Effort De-Radicalization of Religious Understanding." Dalam The Strategic Role of Religious Education in the Development of Culture of Peace. Jakarta: Center for Research and Development of Religious Education and Religion Ministry of Religious Affairs of the Republic of Indonesia, 2012.

http://www.kbbi.web.id/globalisasi, diakses 2 Desember 2016. 